\title{
Siles Artés, José (2006): Antología bilingüe de la poesía angloamericana (Siglos XIV- XX). Ajuntament de L'Eliana (Valencia): La Torre del Virrey. 226 pp.
}

\author{
Reviewed by Enrique Alcaraz Varó \\ University of Alicante
}

La Biblioteca de la Torre del Virrey has just published in 2006 Antologia bilingüe de la poesia angloamericana (Siglos XIV-XX). The first consideration that comes to my mind is to congratulate the Valencian Ajuntament de L'Eliana for this happy enterprise, which is unquestionably a firm step towards the backing and support of true advances in minority cultural movements. These initiatives are most welcome, and should accordingly be openly acknowledged.

Antología bilingüe de la poesía angloamericana (2006) is apparently the second part of Siles's Poesía inglesa: Antología Bilingüe, published in 1979. The ardent fire of Siles's vocation for the challenging enterprise of translating English poetry into Spanish has fortunately not been extinguished at all. On the contrary, it has rekindled, developing into a greater skilfulness, a more refined linguistic elegance, and a fruitful conceptual maturity.

The 1979 Antologia was a smart thin book containing a beautiful bilingual selection of some of the most significant pages of English poetry. It was an outstanding translation. I enjoyed reading it slowly. I cannot help doing 'close reading' with poetry, as I have always relished the analysis of substance and form in a poem. Siles's 1979 Antologia, besides providing me with the pleasure of reading bilingual poetry, served me two purposes: (a) it allowed me to give a second review to some of the canonical poems of English literature that I had read, first in the United States as a high school student, and later in Spain during my university years; and (b) it provided me with very useful material for the teaching of literature.

Now, nearly thirty years later, Siles offers us a new Antología bilingüe de la poesía angloamericana (2006) in a 226-page book, presented in a stylish horizontal format, containing 170 Anglo-American poems. The book consists of six parts, all of which are worth reading; (a) a foreword, (b) a historical outline of the five historical periods of the poems of the book, (c) the poems, (d) a biographical sketch or semblanza of each poet, (e) cultural notes, and (f) an index. Twenty-seven out of the 170 poems of the new Antologia belong to his previous Antologia, but as, Siles claims in the Foreword to the book, he has introduced changes in the old versions, which, using his words, "espero que para mejor".

As a critical reader of both works, the 2006 Antologia displays, to the best of my knowledge, a greater maturity and grace in the mastery of a most appropriate diction of Spanish words, the difficult task of maintaining rhyme and rhythm in Spanish verses, and the not easy task of converting English images into Spanish, always preserving the original meaning and intention.

Although Siles Artés has evidently been guided by his likes and preferences in the selection of the poems, he has also taken into consideration, as he points out in the foreword of the book, those poems that, in his opinion, set new directions in the past towards 
successive movements and schools in the poetry written in the English language. However, I am sure that Siles's experience as a University professor for many years will have likewise oriented him in the careful selection of this antología.

With this idea in mind he has arranged all the material into five parts: (1) Chaucer and the Renaissance, (2) The Civil war, the Restoration and Neoclassicism, (3) The Transition and Romanticism, (4) the Victorian Age, and (5) the $20^{\text {th }}$ century. Most of the authors of this anthology are British. However, we also come across some American poets, not only in $20^{\text {th }}$-century poetry, but in previous periods as well, such as Ralph Waldo Emerson or H. W. Longfellow, who have been included respectively, according to chronological criteria, in the Romantic period (1798-1830) and in the Victorian Age (1830-1900). The historical outline, the biographical sketch or semblanza of each poet and the cultural notes should not be overlooked at all. They are essential, and constitute a part of the whole work. It is obvious that they have been written by an experienced university teacher who is aware of his students' needs. They are like a checklist of the most relevant points.

From my point of view, the audience or readership that could benefit from this book is quite broad. I can see, at least, three groups of readers that will undoubtedly gain a great deal from entering this selected assortment of Anglo American poetry: professionals, university students and the public at large. The first one is formed by professional (or amateur) writers and readers of Spanish and English poetry; university scholars are also included in this group. The second one would consist of university students. Here I make two groups: (1) students doing English Studies in Spanish-speaking countries, and students of Spanish Studies in English-speaking countries; and (2) those doing Translation Studies. The third group, which is the largest, is the general public.

None of these groups will be disappointed after reading this Antologia. The professional writers and readers of Spanish and English will find pleasure in re-reading a careful selection, both in English and Spanish, guided by the scholarship of doctor Siles's work. They will discover or re-discover, for example, the topics of love, beauty and carpe diem of Renaissance poets, the thoughts of Restoration and Neoclassical poetry; the values of freedom and of love of nature, found in the poets of Romanticism; the inventiveness, the defence of strict moral values and the inspired imagination of the so-called Victorian poets; and finally, the multicoloured themes and topics of the troubled $20^{\text {th }}$-century poetry.

For university students doing English Studies or Spanish Studies, this book will be a very helpful tool, as it provides the canonical milestones of Anglo-American poetry. With this book they will be able to understand English poetry in depth, as they discover, from a contrastive point of view, the linguistic devices that carry meaning and produce beauty in two different versions. Students doing translation will have the opportunity to verify in this dual version all the translation techniques that they have learned (thematisation, passivisation, modulations, transpositions, etc.) in their courses. Here are two illustrations of the many examples that can be found in the book:

1. Modulation:

depart to see $\rightarrow$ se juntan (George Herbert, page 37) 
As flowers depart to see their mother-root

Como las flores se juntan con su madre raíz

2. Transposition:

verb (pattering) $\rightarrow$ noun (golpes)

The chestnut pattering on the ground

Golpes de castaña sobre el suelo

Both university groups of students will also have the opportunity to improve their learned vocabulary (sway: mecer, roar: bramar, flit: revolotear, etc.) presented in the context of beautiful poetic utterances.

The fourth group, the public at large, will enjoy not only the pleasure of a beautiful language but will learn as well the wisdom and the sensitivity of these visionary human beings called poets.

In order to attempt an assessment of the value of the translation of the Anglo- American poetry carried out by Siles, we can select as many categories as we wish, which will direct us in our analysis. For my purposes, I will choose only one, faithfulness, which in my opinion embraces many others. The dictionary gives, among others, the following connotations of the word 'faithful': true, loyal, accurate, reliable and credible. Siles has been faithful to the Spanish language and to the original spirit of each poem, as he says "sin desvirtuar sensiblemente el espiritu del original". To this effect, it is very appropriate to appeal to what he says in the foreword: "As I was gaining more self-assurance and confidence, I became more faithful to the Spanish language than to the English language". In my analysis of faithfulness I include both meaning and vividness. When I say vividness I am implying two things at least: the correct diction or appropriate choice of the words, and the successful exploitation of figures of speech in both languages.

If I were an American reviewer I would probably close my assessment with a complimentary sentence stating that this book is worth more than its price. I would also add my admiration for Siles's mastery of both languages and distinguished sensitivity, and for his masterly dexterity in turning the complex and intricate into easy, accessible and enjoyable things.

My warmest congratulations to doctor José Siles Artés for this beautiful gift that he has offered us as a fruit of both his scholarship and his refined aesthetic taste and valuable literary experience as a writer.

Johnston, Bill (2003): Values in English Language Teaching. Mahwah, New Jersey: Lawrence Erlbaum Associates, Publishers.

Reviewed by Juan Ramón Guijarro Ojeda

University of Granada

With a skilful integration of theory and practice, Johnston extends an invitation to readers to enter the world of values, identities, and ELT classrooms. His work is in many respects 
unique in the field of TESOL since it speaks with eloquence to researchers, theorists, and teachers in the wider educational context.

Values in English Language Teaching aims at exploring the complex net of ELT from an axiological point of view to demonstrate that all teaching is value-laden and not just a matter of clear-cut choices. If it is understood coherently, there is something inherently novel and exploratory about an axiological approach to ELT, if only for the reason that no one teacher or learner will ever escape from values. Throughout the whole volume the author provides us with a comprehensive theoretical framework on the topic and outstanding examples taken from real life situations in Brazil, Poland, Japan, Thailand, Turkey, Taiwan, or the USA which render truly illustrative.

Chapter one settles the basis for an educational definition of morals and values considering the field of English Language Teaching. It focuses on the teacher as a moral agent and sets the theoretical and practical underpinnings which inform morality in the ELT classroom following authors such as Noddings or Bauman or documents like the Universal Declaration of Human Rights. Various moral dilemmas are presented under the headings of 'Sociopolitical context': controversy between TESOL culture and target educational cultures; 'Liberation and domination': liberation and domination are issues related to the processes involved in TESOL; and 'Foundations and fundamentalism': the respect for the right to be different clashes with the intolerance sometimes TESOL students show. He clearly states that "ELT teaching in indeed a profoundly moral undertaking" (p. 18).

Chapter two covers such relevant issues as the moral in classroom discourse (what teachers and learners say and do) and its rules and regulations, and the curricular substructure of ESL (textbooks, pronunciation, and writing). To support this idea, Johnston contends that giving priority to structures and functions is itself a form of politics that regulates students' expectations in covert ways. Special attention is paid to the role values play in textbooks as the key element to perpetuate a series of values by dominant and powerful publishers. The set of relations aroused by the interaction between the teacher and the institution are also analyzed as part of the myriad complex situations given by the actions and decisions taken within the classroom. The most important argument to be highlighted is that teachers find themselves constrained by their own values along with the multiple ways these values interact with the students' or situations' values.

Chapter three highlights the core role played by critical pedagogy in the field as a means for creating constructive politics in ELT. References are made to Freire and Giroux and many examples presented to confirm these theories. His discussion revolves around five main areas of politic reference: the use of English in the process of globalization, the use of the English language in the advancement of technology, the education of migrants, the imposition of the English language on indigenous peoples, and language education associated with colonization processes. The view of language teaching as a moral dilemma whose ultimate goal is confronting the moral complexity and ambiguity of our teaching is not without implications for the teacher. This perspective on ELT, which entails the identification of good and right things to do in any given set of circumstances, i.e., "to know the right way to teach" (p. 21), makes the teacher's task more complex than in an 
approach to language teaching based on a positivist view realised by means of a set of preestablished objectives, procedures, and attitudes.

Extremely important is chapter four when it states the morality concerning testing and assessment. It is stated that the act of testing or assessing is an act of valuing, and therefore, subjective. And we are not only valuing a given work, but a given person, which turns the situation highly interesting and controversial at the same time. What to test, whether formal knowledge, procedure or attitudes are central topics to the discussion arena which lead us to judge whether a person is a "good student" or not. Some other areas of interest are the different kinds of assessment, considering relevant issues as how assessment relates to teacher-student relationships, how knowledge of the language is to be assessed or even further, the 'how' in assessing students' effort, participation, motivation, or attitudes which turns highly controversial. Internationally approved TESOL tests like the TOEFL are examined to elucidate the values fostered by standardized tests.

Three aspects of teacher identity are addressed in chapter five to shed light on an area which is certainly unclear because it underlines "who we are". Teachers' own religious beliefs and how to deal with our students' ones are the nitty-gritty of moral dilemmas. Another question addressed is the teachers' involvement in students' lives and how to manage with authority and solidarity towards them. Finally, it is relevant professionalism and the values aroused by the process of assuming a professional identity within the field.

Chapter six places values as a central issue to have into account in teacher development, both when training and developing a professional career. Two models, the European and the North American ones, are discussed on the basis of moral choice. In the former, teacher development equates professional and personal growth and in the latter the presence of teacher educators presented to teachers play a central role. Classroom research is also needed to give values a central role in ELT. There exist the general thought that university research is removed from the "real classroom"; a situation which makes teachers become researchers of their own classrooms to elucidate the morals of the classroom and the true interconnection which take place in it. A central theme here is the way English language teachers and the outsiders perceive the ELT profession and working arena.

Chapter seven is overall reviews of all the topics considered in the book where the various dilemmas have been analyzed from an axiological point of view.

The general aim of the book is demonstrating convincingly that the teaching of language is not a neutral activity; that axiological choices and identities are integral to critical practice; and that those mental or social theories, methods, or techniques are subject to values in the EFL field. Throughout its deep debate around these issues, the author is trying to make ELT teachers consciously aware of the true moral nature of language teaching and learning. ELT teachers will identify closely with the realities of Johnston's examples and will find his reflections at once pedagogically reassuring and theoretically challenging. 
Leo Hickey and Miranda Stewart (eds.) (2005): Politeness in Europe. Clevedon: Multilingual Matters Ltd., 334 pp.

\author{
Reviewed by Victoria Guillén Nieto \\ University of Alicante
}

Back in the 1970s politeness emerged as an area of linguistic interest (Lakoff, 1973, 1975), but, admittedly, it was Brown and Levinson's pioneering formulation of politeness theory (1987 [1978]) which laid the ground for politeness research under a pragmalinguistic perspective, and despite attracting widespread criticism lately, in the opinion of many scholars it has provided the most comprehensive and influential account in the field so far, and widely contributed to the explosion of both intracultural and intercultural research over the last two decades. From this seminal work, it has become clear in Linguistic theory that people do not only speak to one another to transfer information (transactional function) or to do things to one another (Speech Act theory) but also to establish and maintain interpersonal relationships within a particular sociocultural context (interactional function). In recent publications it has also become evident that the way people use language to interact with others is not universal but culture- and language-specific and so, relational communication may vary considerably from one country to another. (Cf. Wierzbicka, 1985, 1991; Matsumoto, 1988; Spencer-Oatey, 2004[2000]).

On the basis that different European societies probably shape socio-cultural distance in different ways, Politeness in Europe aims to give a broad picture of politeness practices across twenty-two of the countries in Europe, and to engage in some of the theoretical debates at the heart of interactional pragmatics. The editors of this volume, Hickey and Stewart, who provide an all-embracing introduction to the latest research in the field, are conscious of the fact that the concept of politeness is problematic, uncertain and confusing, but much more so is the concept of Europe which the authors define as "[...] a loose geographical grouping which is, however, in continuous flux but with political considerations brought in to explain some of the boundaries" (p. 10). All in all, the editors have opted to present the chapters in broad geographical groupings, i.e. Western Europe (Germany, France, Belgium, Luxemburg, The Netherlands, Austria, Switzerland, Britain and Ireland), Northern Europe (Norway, Denmark, Sweden, Finland), Eastern Europe (Estonia, Poland, Hungary and Czech Republic), and Southern Europe (Greece, Cyprus, Italy, Portugal and Spain).

Written by some of today's most prominent European scholars in the field of interactional pragmatics, the twenty-two chapters making up this volume seem to follow a basic analytical pattern in the presentation and development of the ideas. Firstly, mainstream politeness theories, essentially those formulated in the English-speaking world (Brown and Levinson, 1987; Leech, 1983, etc.), are reviewed or, otherwise, some historical background is provided in order to help the reader understand the politeness practices that are in use in a particular nation. Secondly, in some cases, alternative formulations and refinements to Politeness theory are made. Thirdly, these new views are 
tested on a range of related and unrelated languages. A wide range of data has been used and the analytical approach is essentially descriptive and context-based: authentic recordings of spoken discourse in service encounters or telephone conversations, established corpora, written sources, and discourse completion tasks, etc. Fourthly, most of the authors use a broadly comparative approach to shed light on the specificities of the linguistic data they use: this may be between varieties of the same language, broadly cognate languages or unrelated languages, English being used as one of the terms of the comparison in a number of cases. Finally, there is an attempt to deduce overall principles from the data, their purpose being to suggest a communicative profile or ethos for the speech community under study.

Summarising the most relevant contributions of Politeness in Europe, the following issues suggest themselves:

\section{a) Classical debates in Politeness theory}

Based on Brown and Levinson's dominant model, issues such as the degree to which a given society favours conventional usage of formal and informal terms of address, honorifics and personal reference, in general, are among the classical debates that emerge from a number of chapters in this volume. To illustrate this line of research, let us briefly consider the contributions made by Kramer (Luxemburg), Ilie (Sweden), Haumann, Koch and Sorning (Austria), Yli-Vakkuri (Finland), and Huszca (Poland). Kramer (chapter 4, pp. 58-65) finds that all sorts of French and German influences have melted in Luxemburgish giving rise to formulas which either do not exist elsewhere or else are used in pragmatically different ways. Ilie (chapter 12 , pp. 174-188) focuses on the use of the pronominal address forms that become apparent at the interface between language-based politeness rules, institution-based politeness strategies and culture-based communication principles in the Question time sessions of the Swedish Riksdag. Haumann, Koch and Sornig (chapter 6, pp. 82-99) come to the conclusion that in Austria "[...] there is innovation at the same time as there is an adherence to traditional norms as evidenced in the retention of a wide range of titles and honorifics". Yli-Vakkuri (chapter 13, pp. 189-202) maintains that terms of address are used relatively less frequently in Finnish than in many other European languages, their main purpose being to attract the addressee's attention. Another interesting conclusion coming into sight from his investigation on the Finnish politeness system is the use of impersonal, ambiguous or vague expressions when referring to the addressee or to oneself in speech. Last but not least, Huszca (chapter 15, pp. 218233) analyses the complexity of the system of honorifics and forms of address in Polish and reaches the conclusion that "[...] traditionally Polish titlemania is thus gradually decreasing and Polish is moving towards a more transparent, grammaticalised systems of honorifics" (p. 233).

The issue of the degree to which a given society may show preference for the use of either positive or negative politeness strategies is also extensively considered in this volume. Some of the most relevant contributions are those of Kerbrat-Orecchioni (France), 
Kallen (Ireland), and Araújo Carreira (Portugal). Kerbrat-Orecchioni (chapter 2, pp. 2944) stresses the belief that the French conversational style seems, on many fronts, to be halfway between that of the Northern, i.e. independence values and negative politeness strategies, and the Southern European countries, i.e. involvement values and positive politeness strategies. In outlining the Irish ethos, Kallen (chapter 9, pp. 130-144) argues that the full characterisation of Irish politeness must consider the contradiction between the competing demands of silence as a face need, which will tend to favour negative politeness strategies, and the exigency of what he terms hospitality and reciprocity, usually favouring positive politeness. Araújo Carreira (chapter 21, 306-316), for her part, suggests that Portuguese is oriented towards positive politeness, since consensus and tact are favoured over confrontation, frankness or the protection of an individual's territory.

Likewise, some interesting findings as to the use of direct or indirect strategies in the formulation of requests are found in the pieces of research of Le Pair (The Netherlands) and Fretheim (Norway). Le Pair (chapter 5, pp. 66-81), in exploring the connection between the indirectness of speech acts and Leech's tact maxim, finds that factors such as power distance and social distance do indeed affect the directness level of the request utterance in Spanish. Fretheim (chapter 10, pp. 145-158) highlights that linguistic politeness in Norwegian society is characterised by "[...]a tendency toward parsimony: conventionalised indirectness in the performance or requests exists but too much linguistic embroidery for the sake of mitigating requests is normally counter-productive" (p. 158).

\section{b) Alternative formulations and refinements to Politeness theory}

In Politeness in Europe one may also find an attempt to suggest alternative formulations and refinements to Politeness theory. For example, in chapter 1 (pp. 13-28), House, building on Sperber's (1996) naturalistic approach to culture, suggests a ground-breaking and farreaching socio-cognitive model for the understanding of politeness phenomena, uniting universal aspects with culture- and language- specific features.

A basic notion in Brown and Levinson's theory is that of the FTA. They provide a classification of acts according to what aspect of the speaker's or addressee's face is threatened. Though useful, for some authors in this volume this classification may obscure the fact that acts are multidimensional. For example, Kerbrat-Orecchioni (chapter 2, pp. 29-44) in analysing politeness in France, claims that both face-threatening acts (FTAs) and face-flattering acts (FFAs) coexist in the realisation of speech acts. Similarly, Sifianou and Antonopolou (chapter 18, pp. 263-276) put forward the idea that all acts can range on a continuum with face threat occupying one end and face enhancement the other.

The concept of politeness belongs to two traditions: one primarily concerned with conventional courtesy, etiquette or good manners, the other associated with strategic language usage in social interaction, as developed in Brown and Levinson's model. A number of chapters in this volume provide a thorough debate on this matter. Let us consider, for instance, the contribution made by Danblon, De Clerck, and Van Noppen (Belgium), and Stewart (Britain), one of the editors of the volume. Danblon, De Clerck and 
Van Noppen (chapter 3,pp. 45-57) bring to light that Brown and Levinson's model stands at the intersection of two different conceptions of politeness: On the one hand, a rational cooperation-based view and, on the other, one entirely determined by social convention. In testing their reformulation of politeness theory on their extensive data drawn from a number of service encounters in Belgium, they find that neither the customers nor the shop assistants in their sample intend to use politeness markers as strategies aimed at redressing a face-threat; on the contrary, these are used to convey friendliness, good manners and conventional courtesy. Likewise, Stewart (chapter 8, pp. 116-129), in outlining the British ethos, attempts to refine Brown and Levinson's face-saving model when she argues that linguistic politeness may serve a face-protective function for both the Hearer and the Speaker. Consequently, giving preference to indirectness and non-conventional politeness may stem as much from a need to protect one's own face as from any desire to be conventionally polite to others.

The volume does not confine itself to politeness models which merely focus on language, as the role of silence and paralinguistic features are also considered. To illustrate this new line of research, let us consider, for example, the contribution of Fredsted (chapter 11, pp. 159-173) who throws light on the deficit in conventional politeness in Danish by explaining that it is counterbalanced by non-verbal and paralinguistic politeness markers.

\section{c) Ethostereotypes and cross-cultural differences}

In Politeness in Europe, there is a general attempt to characterise the respective ethos or ethnostereotypes of the countries analysed by means of exploring the linguistic and nonlinguistic evidence given by the specific politeness practices under study. Several examples will help me to illustrate this point. In analysing the German politeness system, House (chapter 1, pp. 13-28) finds a consistent pattern in the way Germans subjects tend to interact which is mainly characterised by the following features: (a) directness, (b) orientation towards Self, (c) orientation towards content, (d) explicitness, and (e) ad hoc formulation. Similarly, Keevallik (chapter 14, pp. 203-217) reaches the conclusion that the same German linguistic features could serve to typify the Estonian ethos. Stewart (chapter 8, pp. 116-129), for her part, stresses two essential features that might serve to typify the British ethos: (a) a preference to negative rather than positive politeness strategies which is played out through a number of linguistic strategies, for example, personal reference, hedging and deictic anchorage; (b) the use of off-record politeness also referred to as nonconventional indirectness. However, in other pieces of research, as in the case of Nekvapil and Neustupný's study of politeness in the Czech Republic (chapter 17, pp. 247-262), the authors feel that it is too early to attempt to present an overall picture: "The relationship between politeness and power needs to be clarified but without rushing to premature conclusions" (p. 259).

Cross-cultural differences in linguistic behaviour are other relevant debates emerging from Politeness in Europe. For example, House (chapter 1, pp. 13-28) claims that German speakers' directness should not be misinterpreted as impoliteness, since it is just a culture- 
and language-specific convention. Almost the same conclusion is reached by Keevallik (chapter 14, pp. 203-217) in Estonian, Terkourafi (chapter 19, pp. 277-291) in Cypriot Greek, and Hickey (chapter 22, pp. 317-330), another of the authors of the volume, in Spanish. Kerbrat-Orecchioni (chapter 2, pp. 29-44), in the case of the French politeness system, stresses the fact that interruption should not be misinterpreted as impoliteness but as a discursive device with the main function of helping speed up the tempo of the conversation, give it warmth, and spontaneity. By contrast, Manno (chapter 7, pp.100-115) argues that the Swiss respect for others' right to speak and their tendency not to interrupt each other should not be misinterpreted for apathy.

The chapters in Politeness in Europe are also indicative of the variety of research directions and can serve as the springboard for expansion and new research sites. In this respect, the effect of globalisation and technological advance has created new domains of interaction governed by different rules which are worth exploring: E-mail discourse, web sites, mobile phones, chatlines and internet connections. Recent studies on Network Etiquette or Netiquette for communicating via electronic mail and talk are already pointing in that direction (Shea, 1994; Kallos, 2004). In addition to technological advance, the historical development of politeness norms and practices, which is related to the issue of social structure, class, and power in a particular nation, which has received very little attention so far, would be essential to grasp the socio-cultural roots of politeness practices, as well as the effect of social change.

The book's biggest strengths and weaknesses are different sides of the same coin. On the one hand, Hickey and Stewart provide a never before attempted overview of the politeness practices in twenty-two of the countries of Europe, and lay the ground for a more integrated and deeper understanding of cross-cultural research into politeness phenomena. This is not by any means an easy task since like most of Europe, all the nations included in this volume are in a state of rapid change, stimulated in part by increased European integration, the advance of market economy and globalisation, which leads to a state of constant flux with competition between forms from both main paradigms, the traditional and the modern, in both written and spoken discourse. The editors are absolutely conscious of the present socio-political fluctuations in Europe when they write in the introduction to Politeness in Europe: "[...] as Europe changes and transforms itself, then necessarily its politeness system or systems are also bound to be transformed, and so this volume would need to be rewritten every so often, say every ten years, to update politeness in Europe" (p. 10). On the other hand, the authors in the volume, with the exception of House in chapter 1 (pp. 13-28), may be said, in general terms, to take a traditional approach to politeness phenomena, focusing exclusively on the maintenance and/or promotion of harmonious interpersonal relations. In addition to this, as their contributions are essentially based on Brown and Levinson's dominant politeness framework, they still may be said to look at European politeness practices through Anglo-Saxon spectacles. For this reason, further research on politeness practices in Europe should be extended to incorporate the use of language to promote, maintain or threaten harmonious social relations or rapport management, as suggested by Spencer-Oatey (2004[2000]: 3). Finally, an interdisciplinary 
approach would be much more appropriate in further research on Politeness theory. The crossing of disciplines (Linguistics, Social Anthropology, Social Psychology, etc.) would indeed be crucial to explain in detail the underlying connections linking socio-cultural aspects and politeness practices in a specific society. As mentioned elsewhere, "[...]understanding cultural divergence in communicative styles implies exploring the way in which world dimensions affecting people's patterns of behaviour, beliefs and attitudes, and philosophical maxims have been negotiated in each culture as specific politeness rules and norms of behaviour, and these have become visible in languages". (Guillén Nieto, 2006). By all means, this is an ambitious job but an absolute essential for making the dream of European integration come true: Europe cannot interact appropriately unless its citizens become aware of their culturally diverse and often differing politeness practices. Politeness in Europe does indeed chart the terrain of European politeness research, and lays the foundation for a more integrated cross-cultural understanding of the issue.

\section{References}

Brown, Penelope and Stephen C. Levinson (1978): "Universals in language usage: politeness phenomena". In Questions and Politeness, 56-289. Edited by Esther Goody. Cambridge: Cambridge University Press.

.(1987): Politeness. Cambridge: Cambridge University Press.

Guillén Nieto, Victoria (2006): "Globalisation versus Cultural Diversity: Considerations of Communicative Styles in Intercultural Business Interaction". Paper presented at XXIV AESLA Conference, held in Madrid, from $30^{\text {th }}$ March to $1^{\text {st }}$ April 2006.

Kallos, Judith (2004): Because Netiquette Matters. US: Xlibris Corp.

Lakoff, Robin (1973): "The logic of politeness or minding your p's and q's". In Papers from the Ninth Regional Meeting of the Chicago Linguistic Society, 292-305. Chicago: Chicago Linguistic Society.

. (1975): Language and Woman's Place. New York: Harper and Row.

Leech, Geoffrey N. (1983): Principles of Pragmatics. London: Longman.

Matsumoto, Yoshiko (1988): "Reexamination of the universality of face: politeness phenomena in Japanese". Journal of Pragmatics 12: 403-426.

Shea, Virginia (1994): Netiquette. US: Albion.com Books.

Spencer-Oatey, Helen (2004 [2000]): Culturally Speaking. Managing Rapport through Talk across

Cultures. London/New York: Continuum.

Sperber, Dan (1996): Explaining Culture. A Naturalistic Approach. Oxford: Blackwell Publishers. Wierzbicka, Anna (1985): "Different cultures, different languages, different speech acts. Polish vs. English". Journal of Pragmatics 9: 145-178.

(1991): Cross-Cultural Pragmatics. The Semantics of Human Interaction. Berlin: Mouton de Gruyter. 


\section{Editors' Note}

In last year's volume, inside a review by Dr. José Manuel González Fernández de Sevilla, there were some misprints. They should be read as follows:

Martín, Rodríguez, María, of authorship (p. 309)

in, of, but, Elizabethan (p. 310)

We apologise for the inconvenience this error may have caused.

The editors 